June 2018

\title{
Memories and Milestones
}

Holley Cornetto

San Jose State University, hcornetto@gmail.com

Follow this and additional works at: https://scholarworks.sjsu.edu/ischoolsrj

Part of the Archival Science Commons, Cataloging and Metadata Commons, Collection Development and Management Commons, Information Literacy Commons, Scholarly Communication Commons, and the Scholarly Publishing Commons

\section{Recommended Citation}

Cornetto, H. (2018). Memories and Milestones. School of Information Student Research Journal, 8(1). https://doi.org/10.31979/2575-2499.080101 Retrieved from https://scholarworks.sjsu.edu/ischoolsrj/ vol8/iss $1 / 1$

This article is brought to you by the open access Journals at SJSU ScholarWorks. It has been accepted for inclusion in School of Information Student Research Journal by an authorized administrator of SJSU ScholarWorks. For more information, please contact scholarworks@sjsu.edu. 


\section{Memories and Milestones}

\section{Keywords}

School of Information Student Research Journal, SRJ, San Jose State University, School of Information, iSchool, School of Library \& Information Science

\section{About Author}

Holley Cornetto is an MLIS student at the School of Information at San Jose State University. She is specializing in information intermediation and instruction. Her research interests include information literacy instruction, and library support for distance education students. 
This special issue of The School of Information Student Research Journal (SRJ) highlights the 100,000 download mark for our journal. In this issue, we have invited contributions from Dr. Anthony Bernier, the SRJ's Faculty Adviser, Dr. Sandra Hirsh, Director of San José State University School of Information, and Dr. Mary C. Schutten, Dean of the College of Applied Sciences and Arts (CASA) at San José State University (SJSU).

The $S R J$ was established in 2010 with the goal of creating a student governed publication in the field of library and information science. The $S R J$ is open to submissions from graduate students only, making it one of the best options for students who plan on working in academia or other areas that encourage publication. The exposure to peer review and the revisions process is valuable for aspiring librarians in many fields.

The benefits of the $S R J$ are not only limited to authors, but also extend to the editorial team members. The training in which the $S R J$ editors participate as a part of their duties develops skills that transfer well into the library and information profession as well as other professional areas. Editors develop a keen eye for details, critical thinking skills, communication skills, and the ability to critically evaluate an author's contribution. When asked to reflect on their time as editors for the $S R J$, the most common responses were that the position of editor made students better writers and more aware of problems in his or her own writing. Others focused on the teamwork and collaboration, stating that learning to work as a group in an online environment with people who live across the world was a valuable experience that provided a sense of community.

Volume 8, Issue 1 ends my term as the journal's Editor-in-Chief. This year has been filled with many memories and milestones, including the change on our title and special projects completed by our editorial team members. Reaching 100,000 downloads is a major accomplishment, and I sincerely hope that all past and present editorial team members, authors, and Editorial Advisory Board members feel a sense of accomplishment in this achievement. Every person who has contributed to the success of the $S R J$ is, in some way, a part of this milestone.

\section{Acknowledgements}

I am grateful to Dr. Anthony Bernier for his enthusiasm and support for the SRJ. Learning from him was one of the highlights of my experience. I am grateful to Tamarack Hockin, former EIC, who selected me as her successor. I hope that I have given her no cause to regret her choice. I must also mention Lindsey Travis and Kelly Pollard, both of whom served as Managing Editors during my time as Editor-in-Chief; the journal is better because of your contributions. A special thank you to Dr. Hirsh and Dr. Schutten for taking time out of their busy schedules to provide comments for this issue. The support of the faculty and administration allows $S R J$ to continue to grow and succeed as SJSU's only student governed, double-blind peer reviewed, open-source venue for the dissemination of student research. 